\title{
Spatio-temporal variability of larval abundance and settlement of Perna perna: differential delivery of mussels
}

\author{
Francesca Porri $^{1, *}$, Christopher D. McQuaid ${ }^{1}$, Sarah Radloff $^{2}$ \\ ${ }^{1}$ Coastal Research Group, Department of Zoology and Entomology, Rhodes University, PO Box 94, Grahamstown 6140, \\ South Africa \\ ${ }^{2}$ Department of Statistics, Rhodes University, PO Box 94, Grahamstown 6140, South Africa
}

\begin{abstract}
We examined larval availability and settlement of the intertidal mussel Perna perna simultaneously at different spatial and temporal scales using a nested design at 2 sites, $3 \mathrm{~km}$ apart on the south coast of South Africa. Each site had 3 locations (300 m apart) where 5 artificial settler collectors were placed about $20 \mathrm{~cm}$ apart. Collectors were replaced on temporal scales varying from fortnightly (for $16 \mathrm{mo}$ ) to daily ( 2 series of 15 to $20 \mathrm{~d}$ ). Each intertidal location was paired with an inshore location (these too were $300 \mathrm{~m}$ apart) within $500 \mathrm{~m}$ of the shore, where larval availability was measured by 3 vertical plankton hauls collected on the same dates as for settler sampling. There was strong temporal variation in abundances of larvae and settlers, and no correlation ( $\mathrm{r}$ always $<0.14$ ) was found between the two. Larvae were abundant only at the start of sampling and rare for the rest of the study, while distinct peaks in settler numbers occurred later. No spatial effect was detected for larval availability, while there was strong spatial variation in settlement at the location level. These results indicate that, on scales of $100 \mathrm{~s}$ of $\mathrm{m}$ to $\mathrm{km}$, delivery of larvae from the nearshore water column onto the shore is strongly differential, with some locations consistently receiving more settlers than others. We conclude that, at these sites, the patchiness in settlement observed on scales of $100 \mathrm{~s}$ of $\mathrm{m}$ depends on differential delivery, rather than differential offshore distribution of larvae. We suggest that differential delivery is due to the effect of nearshore bottom topography on local hydrodynamics.
\end{abstract}

KEY WORDS: Perna perna $\cdot$ Settlement $\cdot$ Larval availability $\cdot$ Differential delivery $\cdot$ Mussel $\cdot$ Spatial variability $\cdot$ Temporal variability

\section{INTRODUCTION}

For the past 3 decades, assessing spatial and temporal variability has been one of the major goals of intertidal ecologists trying to understand community organization and population dynamics (Gaines et al. 1985, Menge \& Farrell 1989). For sedentary marine species with planktonic larvae, settlement is a major process, regulating the dynamics and structure of benthic populations (Hunt \& Scheibling 1998, Balch \& Scheibling 2000) and acting as a bridge between dispersal and recruitment. In fact, intertidal community structure and population dynamics are strongly affected by the arrival of larvae on the shore, as settlement rates may determine the final spatial variation of adults (Gaines \& Roughgarden 1985). This is especially true if settlement rates are low (Menge \& Farrell 1989, Menge 2000). Thus, abundances of pelagic larvae and/or settlers can influence the adult population size (Connell 1985, Pulfrich 1996, Norkko et al. 2001, Jeffery 2003) and an understanding of population regulation requires investigation of spawning, dispersal, larval availability and settlement (Gaines \& Bertness 1992, Morgan 2001, Underwood \& Keough 2001).

A problem in studying species with external fertilization and planktonic larvae is that the possible scales of 
dispersal of larvae may range considerably (Roughgarden et al. 1985, Norkko et al. 2001). Dispersal is highly complex and variable, as pelagic larvae exist in a highly patchy and extremely variable environment (McQuaid \& Phillips 2000, Natunewicz \& Epifanio 2001). While some bivalve larvae show active swimming behaviour, controlling their position in the water (Dobretsov \& Miron 2001, Metaxas 2001 for review, Norkko et al. 2001), studies on mussels indicate that larvae are transported passively, without even the vertical migration shown by barnacle larvae (Scheltema 1995, McQuaid \& Phillips 2000, Satumanatpan \& Keough 2001).

Larval patchiness and dispersal are, however, affected by a wide range of factors including seasonality of reproduction (Hurlbut 1991), hydrodynamics, water temperature, geography and topography (Gaines et al. 1985, Pineda 1991, Bertness et al. 1996), which have effects at different spatial scales (Dobretsov \& Miron 2001, Poulin et al. 2002). Temporal variation in larval availability and settlement is also important (Beukema et al. 2001); apart from long-term (e.g. seasonal) variation, abundance in the water column can change dramatically over a short time (e.g. day, hours, seconds; Pulfrich 1997, Poulin et al. 2002). In order to understand the scales of transport and delivery of larvae and to make possible predictions on the future of larvae and the structure of adult populations, dispersal and settlement should be assessed simultaneously (Seed 1976, Suchanek 1985, Underwood \& Keough 2001). Despite this, few studies have inspected the processes, relationships or scales that regulate the passage of invertebrate larvae from nearshore waters to the intertidal, adult habitat (Gaines et al. 1985, Minchinton \& Scheibling 1991, Miron et al. 1995, Pineda et al. 2002).

The present survey is one of the few examples of concurrent investigation of different scales of temporal (seasonal to daily) and spatial (100 $\mathrm{m}$ to $\mathrm{km}$ ) variation in larval availability and settlement. This approach should provide a better understanding of the dynamics and scales that regulate the arrival of pelagic larvae onto the shore (Minchinton \& Scheibling 1991, Jeffery \& Underwood 2000, Jenkins et al. 2000).

Adult mussel densities differ enormously on withinshore scales (Lawrie \& McQuaid 2001, Erlandsson \& McQuaid 2004). This could be due to post-settlement processes, but there is evidence that settlement differs systematically among locations separated by $100 \mathrm{~s}$ of $\mathrm{m}$ (S. Antrobus unpubl. data). Differential settlement could be due to larvae arriving from different pools of larvae, or to differential delivery from nearshore waters to intertidal localities. This study was designed to compare these 2 hypotheses on larval availability and settlement of Perna perna.

\section{MATERIALS AND METHODS}

Study sites. Larval availability and settlement of the mussel Perna perna were investigated (March 2000 to June 2001) on the south coast of South Africa, using a nested approach at 2 sites, Kenton (hereafter KE) and High Rocks (hereafter HR), approximately $3 \mathrm{~km}$ apart $\left(33^{\circ} 41^{\prime} \mathrm{S}, 26^{\circ} 40^{\prime} \mathrm{E}\right)$. At each site, inshore larval abundance was quantified as close to the shore as possible, approximately within $500 \mathrm{~m}$ of the shore, at 3 locations $300 \mathrm{~m}$ apart (positions maintained using a GPS) opposite intertidal locations where settlement was measured at 3 low shore locations with similar mussel cover (approximately $80 \%$ adult cover), $300 \mathrm{~m}$ apart on Aeolian dune rock platforms. All intertidal locations were characterised by the presence of the foliose red alga Gelidium pristoides, with which mussel patches were interspersed.

Larval availability. Inshore larval abundance was quantified from plankton samples collected in the morning on receding spring tides, prior to settlement sampling on the same day, immediately behind the surf zone (within $500 \mathrm{~m}$ of the shore). The water column depth at all offshore locations ranged between 8 and $11 \mathrm{~m}$. Due to possible larval stratification within the water column (McQuaid \& Phillips 2000), sampling was by means of vertical hauls using a plankton net $(80 \mu \mathrm{m}$ mesh, mouth size $30 \times 30 \mathrm{~cm})$, raised from approximately $1 \mathrm{~m}$ above the seabed ( 7 to $10 \mathrm{~m}$ ), in order to minimise sand collection, to the surface at $0.5 \mathrm{~m} \mathrm{~s}^{-1}$. Sampling lasted approximately $1 \mathrm{~h}$. At each location, 3 replicate samples were collected, filtering volumes of water that ranged between 0.5 and $0.8 \mathrm{~m}^{3}$ per replicate. Samples were preserved in $40 \%$ formalin: $60 \%$ seawater. In the laboratory, a few drops of $0.38 \%$ Rose Bengal (acid red, CI45440), in 95\% alcohol, were added to stain the organic material (Garland \& Zimmer 2002). Temporal variation in larval abundance was inspected at different scales from a coarse scale long-term study (fortnightly sampling at spring tides for 14 mo from March 2000 to April 2001 giving 23 sampling events), to fine scale daily studies in 2000 and 2001. Daily sampling was carried out, weather permitting, from 20 March to 10 April 2000 and 6 February to 11 March 2001, when larval abundance was expected to be highest (S. Lawrie unpubl. data).

Settlement. Settlement was investigated from March 2000 to June 2001 using plastic scouring pads as larval collectors (Menge 1992, Menge et al. 1994). Pads were soaked in seawater for 1 to $2 \mathrm{wk}$, before we deployed them among adult mussels. At each location, 5 pads (20 cm apart) were secured to metal screws using plastic cable ties. Pad position changed quite frequently, due to loss of screws. In the laboratory, collected pads 
were agitated and rinsed in $75 \mu \mathrm{m}$ filtered fresh water and the contents examined under a dissecting microscope. Perna perna settlers were identified by shell morphology, counted, measured (0.05 mm precision) and preserved in $70 \%$ alcohol. The shell morphology of $P$. perna larvae and settlers is similar to that of Mytilus galloprovincialis, which also occurs here. However, morphological differentiation between the two has been confirmed by genetic identification (S. Bownes unpubl. data). P. perna settlement consists mainly of primary settlement. However, larger individuals can appear on artificial collectors exposed for just $24 \mathrm{~h}$ (see 'Results'), so a degree of secondary settlement, or dislodgment and re-attachment, may occur.

Temporal variability in settlement was explored at 2 scales including a long-term study (fortnightly sampling at spring tides for 16 mo from March 2000 to June 2001 giving 27 sampling events) and 2 short-term studies with daily sampling in 2000 and 2001. For the longterm study pads were collected after $2 \mathrm{~d}$ on the shore, while for the daily studies pads were replaced after $24 \mathrm{~h}$.

The analyses of larval availability and settlement used data sets with different numbers of dates because the settlement data needed to be balanced due to the loss of pads on some days.

Statistical analysis. Nested ANOVA was performed using STATISTICA 6. Location (3 levels) was nested within Site (2 levels) and orthogonal to Time (23, 17 and 22 levels respectively for the long-term, 2000 and 2001 daily larval studies; 27, 17 and 22 levels for the settlement studies). Spatial factors were treated as random, since the sites used were 'ecological replicates' of the nearshore area and location was nested within site (Zar 1996).

For all studies, the temporal factor, Time, was treated as random. ANOVA tables for random models were made manually following Zar (1996) in order to calculate the degrees of freedom, mean squares and Fratios. The values obtained through the calculation of synthetic mean squares were very similar to the normal construction of mean squares and, therefore, the results of the synthetic means are not presented here. Normality and homogeneity of variances were determined using the Kolmogorov-Smirnov and Cochran's tests respectively. When assumptions of normality and homogeneity could not be satisfied, the dependent variable was logarithmically transformed (Zar 1996, Underwood 1997).

Significant results were tested by post-hoc comparisons using the Student-Newman-Keul's test.

When necessary, data on settlement were balanced using 1 of 2 options. When 1 or 2 of the 5 pads were lost, the mean from the remaining pads was substituted for the missing values. Dates when 3 to 5 pads were lost at 1 or more locations were eliminated from the analysis.

Coupling between the abundance of Perna perna larvae in the water column and settlers on scouring pads was investigated. For each temporal survey, the mean values of larvae collected from the water column on a sampling date were correlated with those for settlers on the shore at the same location and date and the Pearson correlation coefficients (r) calculated. Subsequently, cross-correlation analysis was run for each temporal survey to explore correlations using all possible spatial and temporal lags.

\section{RESULTS}

\section{Larval availability}

Mussels in the plankton ranged in size from $200 \mu \mathrm{m}$ to $1.3 \mathrm{~mm}$, but most $(99.87 \%)$ were between 200 and $400 \mu \mathrm{m}$ and only these individuals were used in the analysis. This range almost overlapped that of animals on settlement pads, representing the size of competent larvae.

\section{Long-term study}

Long-term collections showed peaks in larval distribution at the start of the sampling period, but only on the first 2 dates of collection (20 March and 3 April 2000). For the rest of the study, larvae were extremely rare at both sites (Fig. 1A,B).

Neither site nor location had a significant influence on larval availability ( $p>0.05$ for both; Table 1 ). Nevertheless, the abundance of larvae in the water changed dramatically both at sites and locations during specific collections. There were significant differences in larval variability between sites and among locations on specific sampling dates $(p<0.0001$ for the interactions between Date and Location and Date and Site, Table 1). Total values at HR were $>3$ times greater than at KE (Fig. 1A,B), yet Site alone did not have a significant effect, possibly because the effect of Site was masked by the low numbers of larvae during most of the study and the high temporal variability (effect of Date, $\mathrm{p}<0.0001$, Table 1).

\section{Daily study (2000)}

The numbers of larvae found in the water during the 2000 daily sampling period varied considerably from one day to the next (Fig. 2A,B). Although larval abundance differed among locations, it was not affected by 

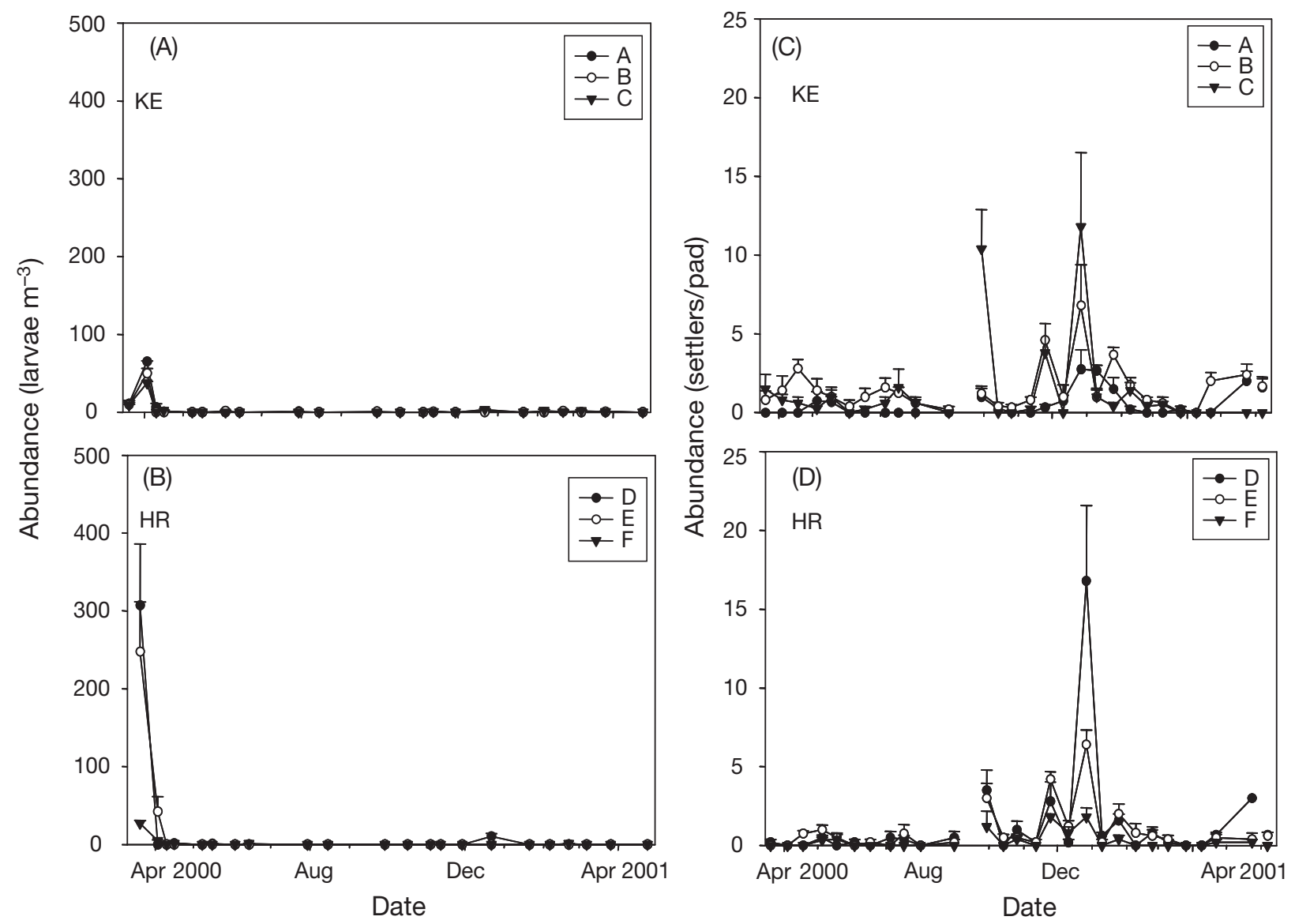

Fig. 1. Perna perna. Long-term larval $(A, B)$ availability and $(C, D)$ settlement at Kenton (KE) and High Rocks (HR). Letters in legend boxes refer to locations in Kenton $(A, B, C)$ and High Rocks (D, E, F). Points indicate mean values and error bars show standard errors (SE)

either Location or Site $(p>0.05$ for both, Table 1), despite drastic differences between sites on the same day and among locations within sites $(\mathrm{p}<0.0001$ for the interactions between Date and Location and Date and Site, Table 1). When larval numbers were high, values peaked at all locations simultaneously, with the single exception of 24 March 2000 at KE. Thus, the interaction between Day and Location reflects the weak spike in larval numbers at KE on 24 March and the fact that, while some locations showed strong peaks, others showed weaker peaks on the same day.

Daily study (2001)

Generally, only small numbers of larvae were collected at both sites and all locations, with extreme variability on a daily scale (Fig. 2C,D). In contrast to 2000, there were no significant effects involving spatial factors and the only significant effects were temporal $(p<$ 0.0001; Table 1).

\section{Settlement}

Settler sizes were more variable than for larvae, with occasional individuals $(23 \%)$ of $\geq 2 \mathrm{~mm}$ shell length. However, most individuals ( $60 \%$ ) were identified morphologically as primary settlers between 200 and $400 \mu \mathrm{m}$, and this was the size class used in the analysis.

\section{Long-term study}

Settler abundance was generally extremely low throughout the study. Although there were clear differences in abundances at different locations, settlers collected at the 2 sites generally showed similar patterns, with a small peak in abundance on 29 September and a bigger one on 27 December 2000 (Fig. 1C,D).

For the settlement study, Time and the smallest spatial scale investigated (Location) affected the variability of settler abundance ( $p<0.0001$ for both; Table 2$)$. On the whole, similar numbers of settlers were found 
at the 2 sites, but the numbers varied significantly among locations ( $p<0.0001$, Table 2).

\section{Daily study (2000)}

Again, numbers were very low at both sites, with mean maximum values of about 2 larvae per pad $\mathrm{d}^{-1}$ (Fig. 3A,B). Even with the low numbers of settlers collected at both sites, there was variability among days and among locations (Fig. 3A,B).

In the present study only Location affected settlement variability significantly ( $p<0.0001$, Table 2 ). Location KE B experienced higher values than all other locations (Fig. 3A,B, Student-Newman-Keul's post-hoc comparison).

\section{Daily study (2001)}

Again, numbers of settlers were very low with high variability on a daily basis and at the location level (Fig. 3C,D).

The results of the 2001 daily settlement study confirmed the strong spatial variability at location level.

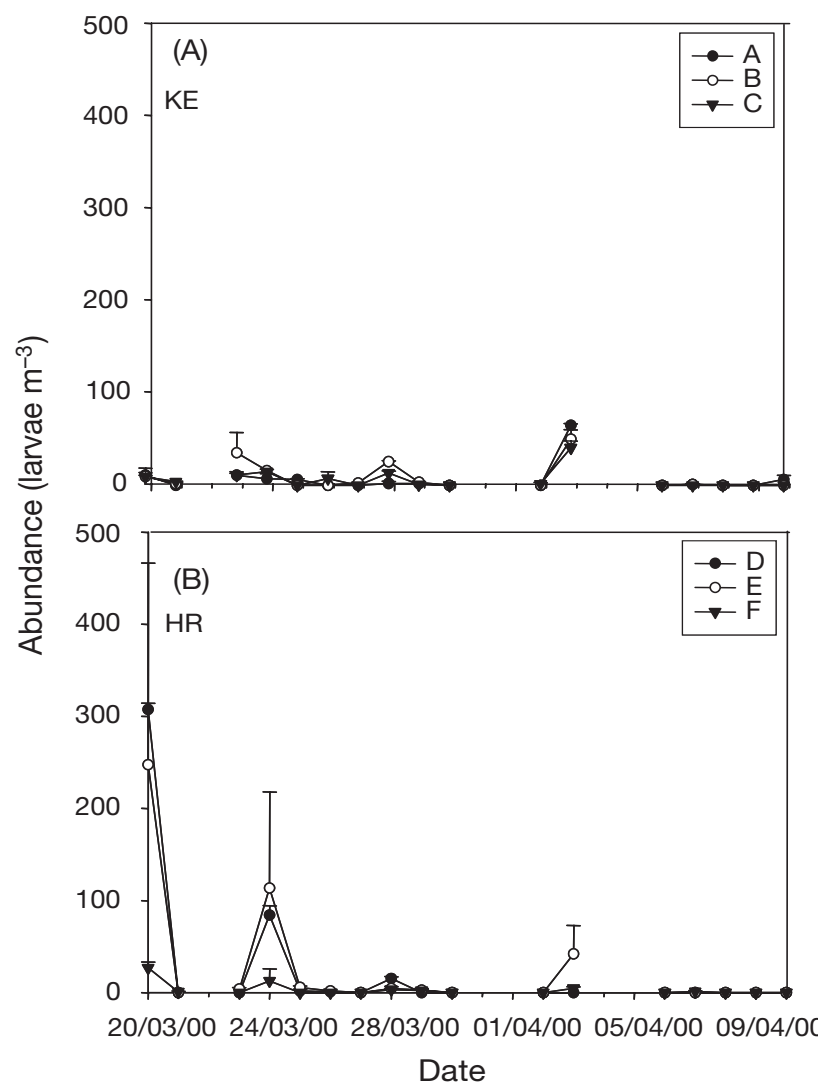

Table 1. ANOVA for larval availability in Perna perna. D: Date, S: Site, Loc: Location, d: Day, E: Error, ns: not significant

\begin{tabular}{|c|c|c|c|c|c|}
\hline & $\mathrm{df}$ & MS & $F$ & $\mathrm{p}$ & Error terms \\
\hline \multicolumn{6}{|c|}{ (a) Long-term study } \\
\hline $\mathrm{D}$ & 22 & 9.071 & 5.537 & $<0.0001$ & $\mathrm{D} \times \mathrm{S}$ \\
\hline $\mathrm{S}$ & 1 & 0.493 & 5.386 & ns & $\operatorname{Loc}(\mathrm{S})$ \\
\hline $\operatorname{Loc}(\mathrm{S})$ & 4 & 0.091 & 0.214 & ns & $\mathrm{D} \times \operatorname{Loc}(\mathrm{S})$ \\
\hline $\mathrm{D} \times \mathrm{S}$ & 22 & 1.638 & 3.827 & $<0.0001$ & $\mathrm{D} \times \operatorname{Loc}(\mathrm{S})$ \\
\hline $\mathrm{D} \times \operatorname{Loc}(\mathrm{S})$ & 88 & 0.428 & 2.352 & $<0.0001$ & $\mathrm{E}$ \\
\hline $\mathrm{E}$ & 138 & 0.182 & & & \\
\hline \multicolumn{6}{|c|}{ (b) Daily study (2000) } \\
\hline $\mathrm{d}$ & 16 & 15.770 & 4.779 & $<0.0001$ & $\mathrm{~d} \times \mathrm{S}$ \\
\hline $\mathrm{S}$ & 1 & 2.334 & 1.786 & ns & $\operatorname{Loc}(\mathrm{S})$ \\
\hline $\operatorname{Loc}(\mathrm{S})$ & 4 & 1.307 & 1.363 & ns & $\mathrm{d} \times \operatorname{Loc}(\mathrm{S})$ \\
\hline $\mathrm{d} \times \mathrm{S}$ & 16 & 3.300 & 3.441 & $<0.0001$ & $\mathrm{~d} \times \operatorname{Loc}(\mathrm{S})$ \\
\hline $\mathrm{d} \times \operatorname{Loc}(\mathrm{S})$ & 64 & 0.959 & 2.411 & $<0.0001$ & E \\
\hline $\mathrm{E}$ & 102 & 0.398 & & & \\
\hline \multicolumn{6}{|c|}{ (c) Daily study (2001) } \\
\hline d & 21 & 13.330 & 4.298 & $<0.0001$ & $\mathrm{~d} \times \mathrm{S}$ \\
\hline $\mathrm{S}$ & 1 & 0.363 & 0.080 & ns & $\operatorname{Loc}(\mathrm{S})$ \\
\hline $\operatorname{Loc}(\mathrm{S})$ & 4 & 4.545 & 1.314 & ns & $\mathrm{d} \times \operatorname{Loc}(\mathrm{S})$ \\
\hline $\mathrm{d} \times \mathrm{S}$ & 21 & 3.101 & 0.896 & ns & $\mathrm{d} \times \operatorname{Loc}(\mathrm{S})$ \\
\hline $\mathrm{d} \times \operatorname{Loc}(\mathrm{S})$ & 84 & 3.459 & 1.285 & ns & E \\
\hline E & 132 & 2.691 & & & \\
\hline
\end{tabular}
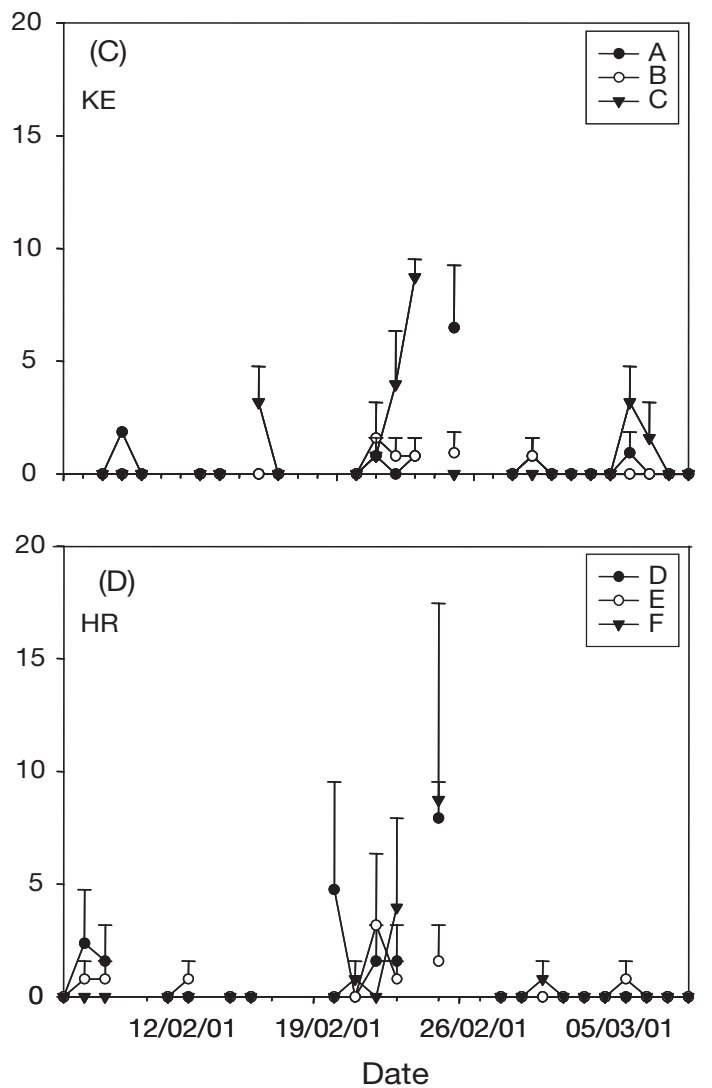

Fig. 2. Perna perna. Daily (A,B) 2000 and (C,D) 2001 larval availability at Kenton (KE) and High Rocks (HR). Letters in legend boxes refer to locations in Kenton (A, B, C) and High Rocks (D, E, F). Points indicate mean values and error bars show standard errors (SE). Dates given as d/mo/yr 

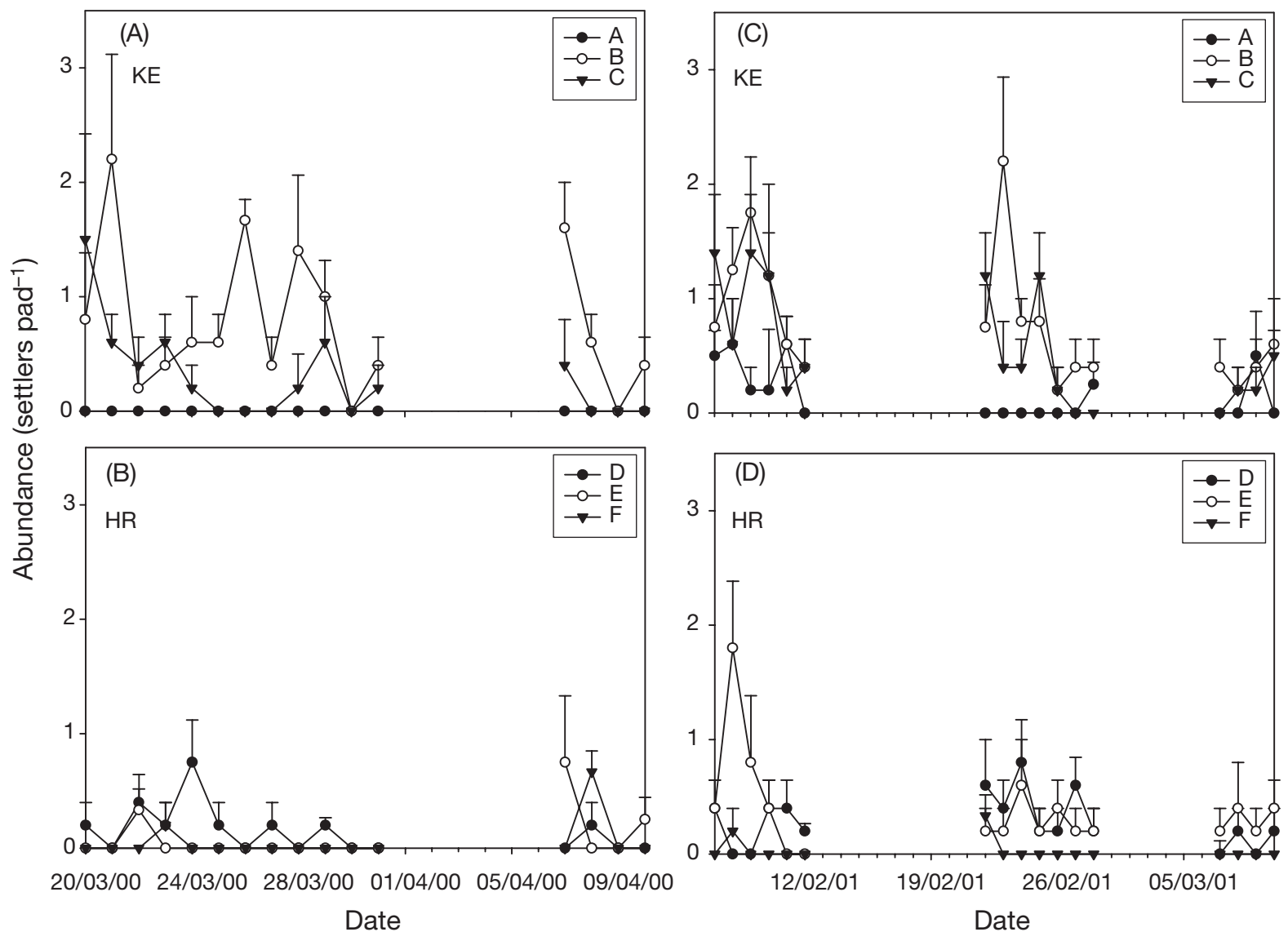

Fig. 3. Daily (A,B) 2000 and (C,D) 2001 settlement at Kenton (KE) and High Rocks (HR). Letters in legend boxes refer to locations in Kenton (A, B, C) and High Rocks (D, E, F). Points indicate mean values and error bars show standard errors (SE). Dates given as $\mathrm{d} / \mathrm{mo} / \mathrm{yr}$

Table 2. ANOVA for settlement in Perna perna. D: Date, S: Site, Loc: Location, d: Day, E: Error, ns: not significant

\begin{tabular}{|c|c|c|c|c|c|}
\hline & df & MS & $F$ & $\mathrm{p}$ & Error terms \\
\hline \multicolumn{6}{|c|}{ (a) Long-term study } \\
\hline $\mathrm{D}$ & 26 & 3.848 & 12.751 & $<0.0001$ & $\mathrm{D} \times \mathrm{S}$ \\
\hline $\mathrm{S}$ & 1 & 4.110 & 1.207 & ns & $\operatorname{Loc}(\mathrm{S})$ \\
\hline $\operatorname{Loc}(\mathrm{S})$ & 4 & 3.404 & 8.223 & $<0.0001$ & $\mathrm{D} \times \operatorname{Loc}(\mathrm{S})$ \\
\hline $\mathrm{D} \times \mathrm{S}$ & 26 & 0.301 & 0.729 & $\mathrm{~ns}$ & $\mathrm{D} \times \operatorname{Loc}(\mathrm{S})$ \\
\hline $\mathrm{D} \times \operatorname{Loc}(\mathrm{S})$ & 104 & 0.414 & 2.388 & $<0.0001$ & $\mathrm{E}$ \\
\hline $\mathrm{E}$ & 648 & 0.173 & & & \\
\hline \multicolumn{6}{|c|}{ (b) Daily study (2000) } \\
\hline d & 15 & 0.632 & 0.909 & ns & $\mathrm{d} \times \mathrm{S}$ \\
\hline $\mathrm{S}$ & 1 & 8.030 & 1.322 & ns & $\operatorname{Loc}(\mathrm{S})$ \\
\hline $\operatorname{Loc}(\mathrm{S})$ & 4 & 6.075 & 11.714 & $<0.0001$ & $\mathrm{~d} \times \operatorname{Loc}(\mathrm{S})$ \\
\hline$d \times S$ & 15 & 0.695 & 1.340 & ns & $\mathrm{d} \times \operatorname{Loc}(\mathrm{S})$ \\
\hline $\mathrm{d} \times \operatorname{Loc}(\mathrm{S})$ & 60 & 0.518 & 1.850 & ns & $\mathrm{E}$ \\
\hline $\mathrm{E}$ & 384 & 0.280 & & & \\
\hline \multicolumn{6}{|c|}{ (c) Daily study (2001) } \\
\hline d & 17 & 1.112 & 1.772 & $\mathrm{~ns}$ & $\mathrm{~d} \times \mathrm{S}$ \\
\hline $\mathrm{S}$ & 1 & 10.027 & 1.727 & ns & $\operatorname{Loc}(\mathrm{S})$ \\
\hline $\operatorname{Loc}(\mathrm{S})$ & 4 & 5.805 & 9.991 & $<0.0001$ & $\mathrm{~d} \times \operatorname{Loc}(\mathrm{S})$ \\
\hline$d \times S$ & 17 & 0.628 & 1.080 & ns & $\mathrm{d} \times \operatorname{Loc}(\mathrm{S})$ \\
\hline $\mathrm{d} \times \operatorname{Loc}(\mathrm{S})$ & 68 & 0.581 & 1.616 & $<0.001$ & $\mathrm{E}$ \\
\hline $\mathrm{E}$ & 432 & 0.359 & & & \\
\hline
\end{tabular}

The temporal scale investigated here, Day, did not significantly affect settlement, although numbers varied amongst locations from day to day (Table 2). Again, KE $B$ showed highest settler numbers (post-hoc $\mathrm{p}<0.05$ ); values at all other locations were generally very low (Fig. 3C,D).

The results emphasise the strong effect of location on settlement at all temporal scales. The larger spatial variable, Site, never influenced settler abundance, though a significant interaction between Time and Site revealed the importance of Site to larval availability during specific sampling events. Neither of the spatial variables had a significant effect as a main factor in any analysis of larval availability. Time, as expected, had an important effect on both larval availability and settlement, with the single exception of the daily settlement studies.

\section{Coupling}

There was no correlation ( $\mathrm{r}<0.14$ for all studies) between larvae in the water and settlers arriving 
ashore. The raw data suggested that the lack of correlation was not due to a lag effect, and this was confirmed by cross-correlation analysis, from which no clear patterns emerged. The long-term data did not show any significant correlation with any lag period. The daily data showed few significant correlations. In 2 cases there were significant correlations between larvae and settlers at the same location with a lag of 2 d. Likewise, analyses comparing settler numbers with larval abundance at other locations occasionally (6 out of 78 spatial comparisons) gave significant results, with lag periods of 1 or $2 \mathrm{~d}$.

\section{DISCUSSION}

Menge \& Farrell (1989) demonstrated a strong biogeographic component to the intensity of recruitment in marine invertebrates, with much less intense recruitment at lower latitudes, though recent studies on spatial variation of barnacle recruitment over a European scale show that this is not always the case (e.g. O'Riordan et al. 2004). Menge \& Farrell (1989) also showed that low settlement rates generally support low adult abundances, although post-recruitment processes (e.g. predation) can also contribute towards the final community structure (Menge \& Farrell 1989, Menge 2000). This highlights the importance of larval dispersal, delivery and settlement in determining whether populations are strongly structured by postsettlement factors such as intraspecific competition for space, or whether they are recruitment limited (Connell 1985). Larvae potentially disperse over large distances (Widdows 1991), but hydrology is important and there is evidence that dispersal may be quite limited (Bhaud et al. 1995). For example, mussel larvae on the south coast of South Africa appear relatively poorly dispersed, with most larvae dispersing over scales of less than $10 \mathrm{~km}$ (McQuaid \& Phillips 2000). In addition, there is evidence of significant differences in recruitment rates on spatial scales of $100 \mathrm{~s}$ of $\mathrm{m}$ within a shore (Lawrie \& McQuaid 2001). This could be explained by differences among locations in post-settlement mortality, but the results of the present study also indicate strong differences in daily settlement rates on such scales. Differences in settlement rates over scales of 100s of $\mathrm{m}$ could be explained by settlers coming from different concentrations of larvae offshore, or by differential delivery of larvae to the shore. Our study was designed to compare these 2 hypotheses.

Although the results of McQuaid \& Phillips (2000) (based on few sampling events) showed drifting of larvae parallel to the shoreline, the present study did not show any correlation between wind and larval abundance or settlement (T. Phillips unpubl. data). We therefore cannot assume an influence of wind on larval transport. The intertidal stations were physically opposite offshore stations. No correlation was found between numbers of larvae and settlers at paired locations. This is unsurprising, as this type of study requires different sampling techniques for the different life stages examined. Our measurements of settlement were cumulative samples, while larval samples were instantaneous spot samples. So, for example, there were occasions when relatively high numbers of settlers were collected, even though the plankton samples contained few or no larvae. Nevertheless, the lack of correlation suggests the importance of the scales of larval transport and delivery as regulated by physical factors, especially local hydrodynamics. Small-scale vertical migrations can be used to influence dispersal in highly stratified environments such as estuaries (DiBacco et al. 2001), but the nearshore water column on this coast is highly mixed due to strong wind-forcing (Goschen \& Schumann 1994) and there is no indication that mussel larvae exhibit diel or other vertical migrations (McQuaid \& Phillips 2000). It thus seems most likely that they are dispersed as passive particles (Bourget 1988). Furthermore, Caceres et al. (1994) found that mussel settlers do not initially show active substratum selection, but tend to stay on the substratum they first encounter through random collisions, and that wave action can control settlement through subsequent mechanical dislodgment. Similarly, laboratory studies by Pernet et al. (2003) showed that mussels can select substrata at low flow rates, but that at high flow rates, as in nature and especially on this coastline, they behave as passive particles.

A methodological problem with the present study is that the time scales of sampling could have partially hidden correlations between larval and settler abundances of Perna perna. An integrated sampling design recording larval abundance in the inshore waters over a period of time is highly desirable (Yund et al. 1991, Setran 1992, Whitlatch \& Osman 1998, Todd 2003) and the use of intertidal larval traps (Castilla \& Varas 1998) was attempted. However, this approach was not possible, as traps became completely clogged with sand within a matter of hours. Similarly, moored plankton nets did not work because of strong wave action.

Our results confirmed high variability in time and space for both larval and settler abundances. Temporal variability in both was great on coarse (seasonal) and fine (daily) scales, with no obvious structure to it. Consequently, reliable or precise predictions of the presence or arrival of larvae cannot be made on this coast. The best we can do is to identify seasonal periods when settlement rates may be high. Throughout the whole study, larvae were abundant only for the period March to April 2000. Otherwise, larvae were rare in 
the water column, in contrast to other studies on the same species in the same area (F. Porri unpubl. data) and $300 \mathrm{~km}$ farther east (Lasiak 1986). Even within months, day-to-day variability in larval abundance was very high in both years. There were also often significant interactions between Time and the smallest spatial scale investigated, Location. Larvae were often abundant at a particular location on a particular day, but not the day after or before.

In contrast to larval data, there were distinct peaks in settler abundance throughout the 16 mo study, with highest abundances in summer. However, even in summer, hydrodynamic conditions in the southern hemisphere are probably less predictable than in the northern hemisphere (Dame 1996), and there was considerable variation in settlement intensity during this season. Coarse temporal effects due to changes in currents from one month to another and among seasons are not unexpected, but fine scale temporal variation in the arrival of larvae on the shore is also influenced by local hydrodynamics (Gaines et al. 1985). Localities may experience settlement at certain times, but not hours, minutes or seconds later, when the water may be calmer or the state of the tide may have changed (Pineda 2000).

Many studies suggest that large spatial scale variation controls the distribution and abundance of larvae offshore, while larval settlement is more influenced by fine scale variability (e.g. Connell 1985, Gaines \& Roughgarden 1985, Pineda 2000). There was little pattern in the spatial variability of larval abundance and, although larval densities varied between sites and locations, neither the site $(\mathrm{km})$ nor the location $(100 \mathrm{~s}$ of $\mathrm{m})$ scales had significant effects. In contrast, location consistently showed a significant influence on settler abundances. The effect of location on settler abundance indicates differential delivery of larvae to this shore at scales of hundreds of meters, i.e. larvae are preferentially transported to some locations rather than others, in this case KE B. Possible explanations for this are that the arrival of larvae at the shore could be locally controlled by coastal morphology, local topography, wave action on the shore (Connell 1985, Jeffery \& Underwood 2000) and by finer scale local micro hydrodynamics, influenced by surface roughness, rock cracks, presence of sessile individuals, pools, channels, protected and exposed shelves (Pineda 2000).

There are other factors that could have influenced differential arrival of larvae among locations. In fact, although we used a standard substratum for settlement, our results could have been influenced by the intensification effect shown in barnacles (Pineda \& Caswell 1997), i.e. settlement patterns influenced by differential availability of suitable substrata. However, there were no obvious differences in mussel cover among locations and differential delivery is a simpler explanation.

Moreover, active choice of substratum or aggregation behaviour, as shown for adult mussels (de Vooys 2003), has not been demonstrated for mussel larvae. Searching for settlement spots or differential availability of substratum can dramatically influence spatial patterns of settlement and survival. For example, on very small spatial scales ( $\mathrm{cm}$ to $\mu \mathrm{m})$, substratum topography or quality (e.g. presence of algal films) can strongly affect survival after settlement of barnacles, hydrozoans and bryozoans (Walters \& Wethey 1996). However, as we used standard artificial settlement substrata (plastic scouring pads) such effects should not influence our results.

Larval availability and settlement are among those parameters with crucial biological importance for the regulation of the spatial and temporal distribution and abundance of marine mussel populations (Morgan 2001, Underwood \& Keough 2001). The results of this study indicate that the physical scales of variability in larval and settler abundances differ, suggesting that, on scales of 100s of $\mathrm{m}$, differential delivery, rather than differential supply of larvae in the water, determines the final distribution of settlers on the shore. We suggest that differential delivery, caused by the effects of small-scale topography on local hydrodynamics, is the best explanation for the transport of larvae to certain locations rather than others.

Acknowledgements. This research was supported by funds from Rhodes University and the Andrew Mellon scholarship of Rhodes University as part of F.P.'s doctorate. Many thanks to all who helped in the field and to L. Benedetti-Cecchi, S. Cannicci and $\mathrm{M}$. Lindergarth for advice on the experimental design and analysis of data.

\section{LITERATURE CITED}

Balch T, Scheibling RE (2000) Temporal and spatial variability in settlement and recruitment of echinoderms in kelp beds and barrens in Nova Scotia. Mar Ecol Prog Ser 205: 139-154

Bertness MD, Gaines SD, Wahle RA (1996) Wind-driven settlement patterns in the acorn barnacle Semibalanus balanoides. Mar Ecol Prog Ser 137:103-110

Beukema JJ, Dekker R, Essink K, Michaelis H (2001) Synchronized reproductive success of the main bivalve species in the Wadden Sea: causes and consequences. Mar Ecol Prog Ser 211:143-155

Bhaud M, Cha J, Duchêne JC, Martin D, Nozais C (1995) Larval biology and benthic recruitment: new ideas on the role of egg-masses and modeling life-cycle regulation. Sci Mar 59:103-117

Bourget E (1988) Barnacle larval settlement: the perception of cues at different spatial scales. In: Chelazzi G, Vannini M (eds) ASI NATO Series A. Life sciences. Plenum Press, New York, p153-172

Caceres-Martinez J, Robledo JAF, Figueras A (1994) Settle- 
ment and post-larvae behaviour of Mytilus galloprovincialis: field and laboratory experiments. Mar Ecol Prog Ser 112:107-117

Castilla JC, Varas MA (1998) A plankton trap for exposed rocky intertidal shores. Mar Ecol Prog Ser 175:299-305

Connell JH (1985) The consequences of variation in initial settlement vs. post-settlement mortality in rocky intertidal communities. J Exp Mar Biol Ecol 93:11-45

Dame RF (1996) Ecology of marine bivalves - an ecosystem approach. CRC Press, Boca Raton, FL

de Vooys CGN (2003) Effect of a tripeptide on the aggregational behavior of the blue mussel Mytilus edulis. Mar Biol 142:1119-1123

DiBacco C, Sutton D, McConnico L (2001) Vertical migration behavior and horizontal distribution on brachyuran larvae in a low-inflow estuary: implications for bay-ocean exchange. Mar Ecol Prog Ser 217:191-206

Dobretsov SV, Miron G (2001) Larval and post-larval vertical distribution of the mussel Mytilus edulis in the White Sea. Mar Ecol Prog Ser 218:179-187

Erlandsson J, McQuaid CD (2004) Spatial structure of recruitment in the mussel Perna perna at local scales: effects of adults, algae and recruit size. Mar Ecol Prog Ser 267: 173-185

Gaines SD, Bertness MD (1992) Dispersal of juveniles and variable recruitment in sessile marine species. Nature 360: $579-580$

Gaines S, Roughgarden J (1985) Larval settlement rate: a leading determinant of structure in an ecological community of the marine intertidal zone. Proc Natl Acad Sci USA 82:3707-3711

Gaines S, Brown S, Roughgarden J (1985) Spatial variation in larval concentrations as a cause of spatial variation in settlement for the barnacle, Balanus glandula. Oecologia 67: 267-272

Garland ED, Zimmer CA (2002) Techniques for the identification of bivalve larvae. Mar Ecol Prog Ser 225:299-310

Goschen WS, Schumann EH (1994) An Agulhas current intrusion into Algoa Bay during August 1988. S Afr J Mar Sci $14: 45-57$

Hunt HL, Scheibling RE (1998) Spatial and temporal variability of patterns of colonization by mussels (Mytilus trossulus, M. edulis) on a wave-exposed rocky shore. Mar Ecol Prog Ser 167:155-169

Hurlbut CJ (1991) The effects of larval abundance, settlement and juvenile mortality on the depth distribution of a colonial ascidian. J Exp Mar Biol Ecol 150:183-202

Jeffery CJ (2003) Determination of abundance and distribution of an intertidal barnacle: settlement or postsettlement mortality? Mar Ecol Prog Ser 246:291-305

Jeffery CJ, Underwood AJ (2000) Consistent spatial patterns of arrival of larvae of the honeycomb barnacle Chamaesipho tasmanica Foster and Anderson in new South Wales. J Exp Mar Biol Ecol 252:109-127

Jenkins SR, Åberg P, Cervin G, Coleman RA and 9 others (2000) Spatial and temporal variation in settlement and recruitment of the intertidal barnacle Semibalanus balanoides (L.) (Crustacea: Cirripedia) over a European scale. J Exp Mar Biol Ecol 243:209-225

Lasiak T (1986) The reproductive cycles of the intertidal bivalves Crassostrea cucullata (Born, 1778) and Perna perna (Linnaeus, 1758) from the Transkei coast, Southern Africa. Veliger 29:226-230

Lawrie SM, McQuaid CD (2001) Scales of mussel bed complexity: structure, associated biota and recruitment. J Exp Mar Biol Ecol 257:135-161

McQuaid CD, Phillips TE (2000) Limited wind-driven disper- sal of intertidal mussel larvae: in situ evidence from the plankton and the spread of the invasive species Mytilus galloprovincialis in South Africa. Mar Ecol Prog Ser 201: 211-220

Menge BA (1992) Community regulation: Under what conditions are bottom-up factors important on rocky shores? Ecology 73:755-765

Menge BA (2000) Recruitment vs. postrecruitment processes as determinants of barnacle population abundance. Ecol Monogr 70:265-288

Menge BA, Farrell TM (1989) Community structure and interaction webs in shallow marine hard-bottom communities: tests of an environmental stress model. Adv Ecol Res 19: 189-262

Menge BA, Berlow EL, Blanchette CA, Navarrete SA, Yamada SB (1994) The keystone species concept: variation in interaction strength in a rocky intertidal habitat. Ecol Monogr 64:249-286

Metaxas A (2001) Behavior in flow: perspectives on the distribution and dispersion of meroplanktonic larvae in the water column. Can J Fish Aquat Sci 58:86-98

Minchinton TE, Scheibling RE (1991) The influence of larval supply and settlement on the population structure of barnacles. Ecology 72:1867-1879

Miron G, Boudreau B, Bourget E (1995) Use of larval supply in benthic ecology: testing correlations between larval supply and larval settlement. Mar Ecol Prog Ser 124:301-305

Morgan SG (2001) The larval ecology of marine communities. In: Bertness MD, Gaines SD, Hay ME (eds) Marine community ecology. Sinauer, Sunderland, MA, p 159-181

Natunewicz CC, Epifanio CE (2001) Spatial and temporal scales of patches of crab larvae in coastal waters. Mar Ecol Prog Ser 212:217-222

Norkko A, Cummings VJ, Thrush SF, Hewitt JE, Hume T (2001) Local dispersal of juvenile bivalves: implications for sandflat ecology. Mar Ecol Prog Ser 212:131-144

O'Riordan RM, Arenas F, Arrontes J, Castro JJ and 13 others (2004) Spatial variation in the recruitment of the intertidal barnacles Chthamalus montagui Southaward and Chthamalus stellatus (Poli) (Crustacea: Cirripedia) over an European scale. J Exp Mar Biol Ecol 304:243-264

Pernet F, Tremblay R, Bourget E (2003) Settlement process spatial pattern and behaviour of mussel larvae Mytilus spp. in experimental 'down-welling' systems of varying velocity and turbulence. Mar Ecol Prog Ser 260:125-140

Pineda J (1991) Predictable upwelling and the shoreward transport of planktonic larvae by internal tidal bores. Science 253:548-551

Pineda J (2000) Linking larval settlement to larval transport: assumptions, potentials, and pitfalls. Oceanogr East Pac 1:84-105

Pineda J, Caswell H (1997) Dependence of settlement rate on suitable substrate area. Mar Biol 129:541-548

Pineda J, Riebensahm D, Medeiros-Bergen D (2002) Semibalanus balanoides in winter and spring: larval concentration, settlement, and substrate occupancy. Mar Biol 140:789-800

Poulin E, Palma AT, Leiva G, Hernández E, Martínez P, Navarrete SA, Castilla JC (2002) Temporal and spatial variation in the distribution of epineustonic competent larvae of Concholepas concholepas along the central coast of Chile. Mar Ecol Prog Ser 229:95-104

Pulfrich A (1996) Attachment and settlement of post-larval mussels (Mytilus edulis L.) in the Schleswig-Holstein Wadden Sea. J Sea Res 36:239-250

Pulfrich A (1997) Seasonal variation in the occurrence of planktic bivalve larvae in the Schleswig-Holstein Wadden 
Sea. Helgol Meeresunters 51:23-29

Roughgarden J, Iwasa Y, Baxter C (1985) Demographic theory for an open population with space-limited recruitment. Ecology 66:54-67

Satumanatpan S, Keough MJ (2001) Roles of larval supply and behavior in determining settlement of barnacles in a temperate mangrove forest. J Exp Mar Biol Ecol 260: 133-153

Scheltema RS (1995) The relevance of passive dispersal for the biogeography of Caribbean molluscs. Am Malacol Bull 11:99-115

Seed R (1976) Ecology. In: Bayne BL (ed) Marine mussels: their ecology and physiology. Cambridge University Press, Cambridge, p 13-65

Setran AC (1992) A new plankton trap for use in the collection of rocky intertidal zooplankton. Limnol Oceanogr 37: $669-674$

Suchanek TH (1985) Mussels and their role in structuring rocky shore communities. In: Moore PG, Seed R (eds) The ecology of rocky coasts. Hodder \& Stoughton, London, p 70-96

Todd CD (2003) Assessment of a trap for measuring larval supply of intertidal barnacles on wave-swept, semi-

Editorial responsibility: Antony J. Underwood (Contributing Editor), Sydney, New South Wales, Australia exposed shores. J Exp Mar Biol Ecol 290:247-269

Underwood AJ (1997) Experiments in ecology — their logical design and interpretation using analysis of variance. Cambridge University Press, Cambridge

Underwood AJ, Keough MJ (2001) Supply-side ecology: the nature and consequences of variations in recruitment of intertidal organisms. In: Bertness MD, Gaines SD, Hay ME (eds) Marine community ecology. Sinauer Associates, Sunderland, MA, p 183-200

Walters LJ, Wethey DS (1996) Settlement and early post-settlement survival of sessile marine invertebrates on topographically complex surfaces: the importance of refuge dimensions and adult morphology. Mar Ecol Prog Ser 137: 161-171

Whitlatch RB, Osman RW (1998) A new device for studying benthic invertebrate recruitment. Limnol Oceanogr 43: 516-523

Widdows J (1991) Physiological ecology of mussel larvae. Aquaculture 94:147-163

Yund PO, Gaines SD, Bertness MD (1991) Cylindrical tube traps for larval sampling. Limnol Oceanogr 36:1167-1177

Zar JH (1996) Biostatistical analysis, 3rd edn. Prentice-Hall, Upper Saddle River, NJ

Submitted: February 28, 2005; Accepted: November 16, 2005 Proofs received from author(s): May 22, 2006 